\title{
Quality of re-ensiled sorghum silages after prolonged periods of environmental exposure
}

\section{Qualidade da silagem de sorgo reensilada após prolongados períodos de exposição ao ambiente}

\author{
Tamires Oliveira de Lima'; Adriano de Almeida Lino ${ }^{2}$; Luis Aurelio Sanches; \\ Vinícius Martins Brito $;$; Sabrina Novaes dos Santos-Araujo ; Milton Augusto \\ Cassiano Sant'Anna ${ }^{3}$; Leandro Coelho de Araujo ${ }^{5 *}$
}

\begin{abstract}
The aim of this study was to evaluate the effect of re-ensiling on the fermentability coefficient (FC), chemical composition and fermentation profile of untreated whole-crop sorghum silage after prolonged periods of environmental exposure. Treatments comprised eight times of exposure to the environment $(0,6,12,24,48,72,96$, and $120 \mathrm{~h})$ and two procedures for conservation (conventional and re-ensiling) in a completely randomized design with two factors and three replicates. Experimental silos made of 12-L plastic buckets were used in trials. Silage nutritive value, fermentation profile, and dry mass (DM) losses were analyzed before and 90 days after re-ensiling. Regression analyses were performed, and ANOVA was used to compare means. The FC was higher than 45 even when the silage was exposed to air for $120 \mathrm{~h}$ before re-ensiling $(59.2 \pm 2.54)$. Regression equations were fitted to the data with low accuracy $\left(\mathrm{R}^{2}<0.47\right)$. Moreover, we observed that the main effect occurred between before and after re-ensiling, decreasing the contents of DM (42 to $37 \%$ ) and water-soluble carbohydrates ( 7.0 to $5.8 \%$ $\mathrm{DM})$, neutral detergent fiber (60.4 to $55.4 \% \mathrm{DM}$ ), and acid detergent fiber (49.5 to $33.5 \% \mathrm{DM})$, but increasing those of lactic acid $(0.52$ to $0.96 \% \mathrm{DM})$ and ammoniacal nitrogen $(1.58$ to $2.51 \%$ total $\mathrm{N})$. The DM losses were linear with increasing times of air exposure; however, silage nutritive value and fermentation profile showed no disturbing changes for silage conservation and animal feeding.
\end{abstract}

Key words: Ammonia nitrogen. Fermentation. Recompaction. Tropical forage.

\section{Resumo}

O objetivo com este estudo foi avaliar o efeito da reensilagem sobre o coeficiente de fermentação (CF), bromatologia e fermentação de silagens de plantas inteiras de sorgo após períodos de exposição ao ambiente. Os tratamentos corresponderam a oito tempos de exposição ao ambiente $(0,6,12,24,48,72$, 96 e $120 \mathrm{~h}$ ) e dois procedimentos de conservação (silagem convencional e reensilada), no delineamento inteiramente casualizado com dois fatores e três repetições, utilizando-se silos experimentais de $12 \mathrm{~L}$. Os silos foram abertos 90 dias após o fechamento e analisados o valor nutritivo, o perfil fermentativo e

${ }^{1}$ Discente de Graduação em Engenharia Agronômica, Faculdade de Engenharia, UNESP, Ilha Solteira, SP, Brasil. E-mail: lima96agro@gmail.com

2 Discente de Graduação em Zootecnia, UNESP, Ilha Solteira, SP, Brasil. E-mail: adrlino@gmail.com

3 Discentes de Mestrado, Programa de Pós-Graduação em Ciência e Tecnologia Animal, UNESP, Ilha Solteira, SP, Brasil. E-mail: luiz.pontalinda@gmail.com; vinicius_brito13@hotmail.com; miltonveterinario@hotmail.com

4 Pesquisadora, Co-orientadora, Programa de Pós-Graduação em Ciência e Tecnologia Animal, UNESP, Ilha Solteira, SP, Brasil. E-mail: sabrinanovaes@usp.br

5 Prof., UNESP, Ilha Solteira, SP, Brasil. E-mail: leandro.araujo@unesp.br

* Author for correspondence 
as perdas de massa seca (MS). Foram ajustadas regressões e a ANOVA foi utilizada para comparação entre médias. O CF foi maior do que 45, mesmo quando a silagem foi exposta ao ambiente por $120 \mathrm{~h}$ antes a reensilagem $(59,2 \pm 2,54)$. As equações de regressão foram ajustadas com baixa precisão $\left(\mathrm{R}^{2}<\right.$ $0,47)$ e foi observado que o principal efeito ocorreu entre os procedimento de conservação e não para os tempos de exposição, reduzindo o conteúdo de MS (42 para $37 \%$ ) e carboidratos solúveis em água (7,0 para 5,8 \% da MS), fibras em detergente neutro (60,4 para 55,4\% da MS) e ácido (49,5 para 33,5 $\%$ da MS), e aumentando os teores de AL (0,52 para 0,96 \% da MS) e $\mathrm{N}^{-N_{3}}$ ( 1,58 para 2,51 \% do N total). As perdas de MS foram lineares com o tempo de exposição ao ambiente, no entanto, não foram observadas mudanças impactantes no valor nutritivo das silagens com o processo de reensilagem.

Palavras-chave: Fermentação. Foragem tropical. Nitrogênio amoniacal. Recompactação.

Silage is made by storing of green forage in bunkers and then allowing it to ferment. Reensiling, in turn, is the repacking of silage into small bags and round bales or recompacting of material in bunkers. The re-ensiled silage market has increased continuously in Brazil, especially in important dairy-producing regions where land topography, weather, and the lack of specific agricultural implements and machinery limit traditional silage making techniques.

Re-ensiling offers the possibility of dividing large quantities of silage stored in bunkers, trenches, or stacks into smaller units, which can be easily transported and sold. Re-ensiled silage is an interesting strategy as it rearranges remaining silages in farms. However, further research must be carried out to address such an issue since there are is no technical recommendation for this technique.

Silage quality can be determined by how long it remains stable during environmental exposure. In this sense, several are the factors influencing it such as air temperature, forage species, dry matter (DM) concentration, $\mathrm{O}_{2}$, and $\mathrm{CO}_{2}$ fluxes, yeast and mold populations, and concentrations of organic acids and residual water-soluble carbohydrates (WSC) (McDonald, Henderson, \& Heron, 1991).

Silage deterioration is initiated mainly by acidtolerant yeasts that ferment lactic acid (LA) and residual WSC of silages to $\mathrm{CO}_{2}, \mathrm{H}_{2} \mathrm{O}$, and heat, raising the $\mathrm{pH}$ and thus allowing the germination and growth of undesirable microbial spores (McDonald et al., 1991). Aerobic deterioration is increasingly worrying in warmer environments due to speeding up of processes, since yeasts and molds are more active in high temperatures (Ashbell, Weinberg, Hen, \& Filya, 2002), such as in Brazil.

Research has shown that the aerobic stability of untreated corn silages may range up to 50 hours $(\mathrm{Hu}$, Schmidt, McDonell, Klingerman, \& Kung, 2009). This suggests that re-ensiling should be performed within this time to avoid DM and silage quality losses. However, studies on the quality of re-ensiled silages in Brazil, Israel, and the United States have shown no changes in their chemical composition after an environmental exposure of $48 \mathrm{~h}$ for corn, wheat (Chen \& Weinberg, 2014), and whole-crop sorghum (Michel et al., 2016).

Given the above, the aim of this study was to evaluate the effect of re-ensiling on the fermentability coefficient (FC), DM losses, chemical composition, in vitro organic matter digestibility (IVOMD), and acidification of untreated whole-crop sorghum silage after prolonged periods of environmental exposure.

The trial was carried out in Ilha Solteira, SP, Brazil (203' 44" S, 51 06 '35" W; 347 m altitude). According to Köppen's classification, the climate of the region is $A w$ (tropical humid), with rainy summers and dry winters, and an average annual air temperature of $24.7^{\circ} \mathrm{C}$, accumulated precipitation of $1,360 \mathrm{~mm}$, and relative humidity of $75 \%$. Sorghum [Sorghum bicolor (L.) Moench cv Volumax] plants were ensiled without chemical additives or microbial inoculants. It was chopped into pieces of 2 -cm length and compacted in a concrete bunker silo with dimensions $2.5 \times 4.45 \times 30 \mathrm{~m}$ (length $\mathrm{x}$ width $\mathrm{x}$ height) and sealed with plastic film. 
The bunker silo was opened ten months after it was sealed. Silage samples were collected from the face of the silage and quickly stored in plastic bags, which remained open and stored under a covered building, thus providing exposure to air, and avoiding rain and direct solar radiation. A completely randomized design with two factors and three replicates was adopted. The first factor comprised eight times of silage exposure to air $(0,6,12,24,48,72,96$, and $120 \mathrm{~h})$, while the second factor comprised two procedures for silage conservation (conventional or re-ensiling).

Silage samples were stored inside plastic bags and remained in contact with air until being reensiled. They were homogenized inside plastic bags once every $24 \mathrm{~h}$ and before re-ensiling. These procedures were carried out in an indoor room.

The samples were dried in a forced air ventilation oven at $60{ }^{\circ} \mathrm{C}$ until constant weight and then ground to $1 \mathrm{~mm}$ to determine the original contents of DM $\left(105{ }^{\circ} \mathrm{C}, 24 \mathrm{~h}\right)$, crude protein $(\mathrm{CP}$; Association of Official Analytical Chemistry [AOAC], 1990), ether extract (EE; Soxhlet extractor), neutral and acid detergent fiber (NDF and ADF) by sequential method (Robertson \& Van Soest, 1981), ammoniacal nitrogen-total nitrogen ratio $\left(\mathrm{NH}_{3}-\mathrm{N}\right)$, WSC (Johnson, Balwani, Johnson, McClure, \& Dehority, 1966), and IVOMD (Tilley \& Terry, 1963) using a digestibility test incubator (Marconi, MA443/E). The buffering capacity (BC) was determined using the method of Playne and McDonald (1966) and expressed as $\mathrm{mEq} \mathrm{kg}^{-1} \mathrm{DM}$.

Samples were pressed in a manual screw to extract juice, and the $\mathrm{pH}$ was measured using $\mathrm{pH}$ meter. To quantify $\mathrm{NH}_{3}-\mathrm{N}$ (AOAC, 1990) and AL (Pryce, 1969) contents, silage juices were stored in amber glass bottles and frozen $\left(-20^{\circ} \mathrm{C}\right)$ until analyses.

Fermentability coefficient was calculated as $D M$ $\left(\mathrm{g} 100 \mathrm{~g}^{-1}\right)+8 \cdot W S C\left(\mathrm{~g} \mathrm{~kg}^{-1}\right.$ of DM $) / B C\left(\mathrm{~g} \mathrm{LA} \mathrm{kg}^{-1}\right.$ of $\mathrm{DM})$, and $\mathrm{BC}$ was calculated following the method of Clavin, Crosson, Grant and O'Kiely (2017). All analyses performed in silages before re-ensiling were also carried out after re-ensiling.
Silages were re-ensiled into 12-L plastic buckets (505 $\left.\mathrm{kg} \mathrm{m}^{-3} \mathrm{OM}\right)$ using a manual screw, with appropriate lids to ensure adequate sealing, allowing only the gases emitted from fermentation to escape through a Bunsen-type valve. At the bottom of each silo, a cotton bag containing about $2 \mathrm{~kg}$ of dry sand was placed to collect effluent. At 90 days after sealing, the silos were opened and DM loss through gases and effluent was calculated as the difference between final and initial weights. Then, the total DM recovered from silos was also estimated.

All statistical analyses were performed using SPSS $^{\circledR}$ Statistics $\left(\mathrm{IBM}^{\circledR}\right.$, version 22), using a model appropriate for a completely randomized design with treatments arranged in an $8 \times 2$ factorial structure and three replicates:

$$
Y_{i j k}=\mu+\alpha_{i}+\beta_{j}+(\alpha \beta)_{i j}+\varepsilon_{i j k}
$$

where $\mu=$ overall means, $\alpha_{\mathrm{i}}=$ exposure times to air ( $\mathrm{i}=$ $0,6,12,24,48,72,96$, and $120 \mathrm{~h}), \beta_{\mathrm{j}}=$ procedures for conservation ( $j=$ conventional or re-ensiling), $(\alpha \beta)_{i j}=$ effect of interaction between exposure times and conservation procedures, and $\varepsilon_{\mathrm{ijk}}=$ random error.

The variables were subjected to preliminary exploratory analysis to identify outliers and check basic prerequisites for analysis of variance ANOVA (linearity, homoscedasticity, and normality of errors). The effect of exposure times to air on the analyzed variables were fitted separately for conventional (before) and re-ensiled (after) silages, using simple linear or quadratic regressions. ANOVA was used to compare means before and after re-ensiling, and the standard error of the mean (SEM) was taken as indicative of dispersion. Differences were considered significant at $\mathrm{P}<0.05$.

All silages showed FC of $59.2 \pm 2.5$ before re-ensiling, ensuring good conditions for silage fermentation. Before re-ensiling, CP decreased linearly $0.0015 \%$ per hour of environmental exposure while $\mathrm{pH}, \mathrm{WSC}, \mathrm{EE}, \mathrm{NH}_{3}-\mathrm{N}$, and $\mathrm{BC}$ showed a quadratic fitting, and their derivatives were respectively 3.7 (55 h), 6.2 \% DM (83 h), 1.8 $\%$ DM (24 h), 1.9 (68 h) \% total N, and $20.6 \mathrm{~g} \mathrm{LA}$ $\mathrm{kg}^{-1} \mathrm{DM}(69 \mathrm{~h})$ (Table 1). 
Table 1

Effect of exposure time to the environment on sorghum silages before and after re-ensiling

\begin{tabular}{|c|c|c|c|c|c|c|c|c|c|c|c|c|}
\hline \multirow[t]{2}{*}{ Item } & \multicolumn{8}{|c|}{ Treatment (h) } & \multirow{2}{*}{ Means } & \multirow{2}{*}{ SEM } & \multicolumn{2}{|c|}{ Effect $^{1}$} \\
\hline & 0 & 6 & 12 & 24 & 48 & 72 & 96 & 120 & & & $\mathrm{~L}$ & Q \\
\hline & \multicolumn{12}{|c|}{ Before } \\
\hline $\mathrm{pH}$ & 3.8 & 3.8 & 3.8 & 3.8 & 3.7 & 3.7 & 3.7 & 3.8 & $3.77 \mathrm{a}$ & 0.010 & NS & $*$ \\
\hline $\mathrm{DM}, \%$ & 41.5 & 41.2 & 41.1 & 41.6 & 41.0 & 44.4 & 41.6 & 40.6 & $41.61 \mathrm{a}$ & 0.300 & NS & NS \\
\hline IVOMD, \% & 64.8 & 58.3 & 61.9 & 65.1 & 63.7 & 62.1 & 62.7 & 60.5 & $62.36 \mathrm{~b}$ & 0.930 & NS & NS \\
\hline $\mathrm{CP}, \% \mathrm{DM}$ & 4.4 & 4.3 & 4.4 & 4.4 & 4.1 & 4.2 & 4.2 & 4.2 & $4.26 \mathrm{~b}$ & 0.030 & $*$ & NS \\
\hline WSC & 7.4 & 7.6 & 7.4 & 7.0 & 6.4 & 6.3 & 7.0 & 7.1 & $7.03 \mathrm{a}$ & 0.333 & $* *$ & $* *$ \\
\hline NDF & 59.3 & 59.9 & 60.4 & 59.4 & 59.8 & 59.0 & 64.0 & 62.4 & $60.36 \mathrm{a}$ & 0.436 & NS & NS \\
\hline $\mathrm{ADF}$ & 49.2 & 48.7 & 48.7 & 47.2 & 49.0 & 48.3 & 53.7 & 51.6 & $49.54 \mathrm{a}$ & 0.295 & NS & NS \\
\hline $\mathrm{EE}$ & 1.7 & 1.9 & 1.7 & 1.8 & 1.7 & 1.8 & 1.5 & 1.3 & 1.67 & 0.072 & $*$ & $*$ \\
\hline $\mathrm{N}-\mathrm{NH}_{3}, \%$ total $\mathrm{N}$ & 0.74 & 0.93 & 1.72 & 1.48 & 1.89 & 2.05 & 1.84 & 1.99 & $1.58 \mathrm{~b}$ & 0.085 & $*$ & $*$ \\
\hline LA, \% DM & 0.30 & 0.34 & 0.58 & 0.64 & 0.56 & 0.57 & 0.55 & 0.57 & $0.51 \mathrm{~b}$ & 0.010 & NS & NS \\
\hline \multirow[t]{2}{*}{$\mathrm{BC}, \mathrm{g} \mathrm{LA} \mathrm{kg}^{-1} \mathrm{DM}$} & 22.6 & 23.6 & 22.9 & 22.4 & 21.4 & 19.8 & 21.7 & 22.9 & $22.15 \mathrm{~b}$ & 0.413 & NS & $*$ \\
\hline & \multicolumn{12}{|c|}{ After } \\
\hline $\mathrm{pH}$ & 3.2 & 3.3 & 3.3 & 3.3 & 3.3 & 3.3 & 3.3 & 3.3 & $3.29 \mathrm{~b}$ & 0.010 & NS & NS \\
\hline $\mathrm{DM}, \%$ & 36.3 & 36.3 & 37.2 & 37.7 & 37.5 & 38.9 & 36.9 & 38.8 & $37.45 \mathrm{~b}$ & 0.364 & $*$ & $*$ \\
\hline IVOMD & 69.0 & 62.9 & 69.5 & 61.1 & 68.8 & 64.6 & 66.0 & 66.5 & $66.04 \mathrm{a}$ & 0.598 & NS & NS \\
\hline $\mathrm{CP}, \% \mathrm{DM}$ & 4.5 & 4.6 & 4.6 & 4.5 & 4.4 & 4.6 & 4.6 & 4.5 & $4.56 \mathrm{a}$ & 0.043 & NS & NS \\
\hline WSC & 6.58 & 6.02 & 4.62 & 5.81 & 6.80 & 6.2 & 4.6 & 5.99 & $5.82 \mathrm{~b}$ & 0.137 & NS & NS \\
\hline NDF & 54.7 & 55.6 & 55.2 & 56.9 & 57.0 & 55.6 & 53.1 & 54.8 & $55.37 \mathrm{~b}$ & 0.611 & NS & $*$ \\
\hline $\mathrm{ADF}$ & 32.9 & 33.6 & 34.2 & 34.2 & 33.9 & 33.3 & 33.8 & 32.4 & $33.54 \mathrm{~b}$ & 0.665 & NS & * \\
\hline $\mathrm{EE}$ & 1.8 & 2.3 & 1.5 & 1.5 & 1.4 & 1.4 & 1.4 & 1.7 & 1.58 & 0.050 & NS & NS \\
\hline $\mathrm{N}-\mathrm{NH}_{3}, \%$ total $\mathrm{N}$ & 2.9 & 2.8 & 2.4 & 2.6 & 2.4 & 2.1 & 2.5 & 2.3 & $2.51 \mathrm{a}$ & 0.129 & * & NS \\
\hline LA \% DM & 1.16 & 1.10 & 0.93 & 0.93 & 0.89 & 0.80 & 1.05 & 0.80 & $0.96 \mathrm{a}$ & 0.006 & $*$ & NS \\
\hline $\mathrm{BC}, \mathrm{g} \mathrm{LA} \mathrm{kg}^{-1} \mathrm{DM}$ & 27.3 & 26.9 & 26.4 & 26.9 & 28.0 & 27.0 & 30.4 & 27.4 & $27.29 \mathrm{a}$ & 0.363 & NS & NS \\
\hline Gas, \% DM & 12.3 & 11.7 & 9.5 & 9.4 & 8.4 & 10.9 & 10.9 & 4.7 & 9.73 & 0.692 & $*$ & NS \\
\hline Effluent, $\mathrm{L} \mathrm{t}^{-1} \mathrm{OM}$ & 22.1 & 21.9 & 21.2 & 21.3 & 21.4 & 21.4 & 21.8 & 21.4 & 21.58 & 0.171 & NS & NS \\
\hline DM recovery, \% & 87.7 & 88.6 & 90.6 & 90.6 & 91.6 & 89.1 & 89.1 & 95.3 & 90.28 & 0.664 & $*$ & NS \\
\hline
\end{tabular}

Means within a column with different superscripts are significantly different $(* \mathrm{P}<0.05) . \pm \mathrm{M}=\mathrm{Standard}$ error of the mean. $\mathrm{DM}=$ dry mass, $\mathrm{CP}=$ crude protein, $\mathrm{EE}=$ ethereal extract, $\mathrm{NDF}=$ neutral detergent fiber, $\mathrm{ADF}=$ acid detergent fiber, $\mathrm{LA}=$ lactic acid, $\mathrm{NH}_{3}-\mathrm{N}=$ ammoniacal nitrogen-total nitrogen ratio, WSC $=$ water-soluble carbohydrates, $\mathrm{BC}=$ buffering capacity, and IVOMD $=$ in vitro organic matter digestibility.

After re-ensiling, DM, NDF, and ADF increased respectively up to $37.9 \%$ (85 h), $56.1 \% \mathrm{DM}$ (45 h), and $34.0 \% \mathrm{DM}(44 \mathrm{~h})$ during environmental exposure of silages, and $\mathrm{NH}_{3}-\mathrm{N}, \mathrm{AL}$, gases, and DM recovery were linearly fitted between the environmental exposure time, with slopes of $-0.0042 \%$ total N, $-0.0018 \%$ DM, $-0.0334 \%$ DM, and $0.0322 \% \mathrm{DM}$, respectively. However, these regression equations were fitted with low precision since $\mathrm{R}^{2}$ was lower than 0.47 , except for WSC before re-ensiling $\left(\mathrm{R}^{2}=0.70\right)$. Thus, we observed that the main effect occurred between before and after re-ensiling (Table 1).

After re-ensilage, the contents of DM (41.6 to $37.4 \%, \mathrm{P}<0.05)$ and WSC $(7.0$ to $5.8 \% \mathrm{DM}$, $\mathrm{P}<0.05)$ decreased, whereas those of LA $(0.52$ to 
$0.96 \% \mathrm{DM}, \mathrm{P}<0.05)$ and $\mathrm{NH}_{3}-\mathrm{N}(1.58$ to $2.51 \%$ total $\mathrm{N}, \mathrm{P}<0.05$ ) increased (Table 1).

According to the treatments, no differences were observed neither for gas and effluent losses nor DM recovery after re-ensiling, and the averages were $9.73 \mathrm{DM}, 21.58 \mathrm{~L} \mathrm{t}^{-1} \mathrm{OM}$, and 90.3\% DM, respectively (Table 1 ).

The average FC before re-ensiling was higher than 45 , which is recommended to ensure a good silage quality. Therefore, the silage did not lose its characteristics to ensure good fermentability, even after $120 \mathrm{~h}$ of environmental exposure. The DM was the main parameter that contributed to such a high $\mathrm{FC}$, which may be due to its high correlation ( $\mathrm{r}=$ $0.86, \mathrm{P}<0.05$ ) and for remaining constant at $41 \%$ over time.

After re-ensilage, the contents of $\mathrm{DM}$ and WSC decreased, while LA and $\mathrm{NH}_{3}-\mathrm{N}$ increased, indicating microbial activity even after a long exposure period of the silages to air. High contents of $\mathrm{NH}_{3}-\mathrm{N}$ indicate high levels of proteolysis due to fermentation of amino acids by proteolytic Clostridium (McGechan, 1989). Proteolysis might occur during fermentation until acidic conditions inactivate undesirable microorganisms. The fermentation of WSC by LA bacteria, as well as WSC and AL by Clostridium generates water (McDonald et al., 1991), which explains the decrease in DM content after re-ensiling.

A decrease in NDF and ADF levels was observed after re-ensiling and an ensuing increase in IVOMD. Changes in fiber contents may be attributed to cell wall degradation by the activity of bacterial enzymes and acidic condition in silages, as reported by Sariçiçek, Yildirim, Kocabaş and Özgümüş Demir (2016) for corn silages, and by Yahaya et al. (2001) for alfalfa and orchard grass silages. The authors observed losses of hemicellulose and pectin fractions between fresh forage and silage.

Crude protein content increased after reensilage, but not significantly for ration formulation since the value is considered low in both conditions. As microbial nitrogen had no significant increase during silage fermentation, such an increase in $\mathrm{CP}$ is due to DM losses, which increase CP concentrations in silages.

Dry mass was recovered after re-ensiling, indicating DM balance after the fermentation process. The remaining silage will be available to feed cattle after the silo is opened; therefore, strategies to increase DM recovery are crucial to reduce production costs and avoid silage deficit. The DM recovered in this trial was of $90.3 \%$, higher than that reported by Michel et al. (2016) of $83 \%$ for sorghum silages re-ensiled after $24 \mathrm{~h}$ of air exposure. According to the results, fermentation occurs even in the material that has already fermented during the first ensilage. Fermentation continues even after re-ensiling because if the substrate is available, LA bacteria continue their metabolic activity. However, all ensiling precautions should continue during reensiling to minimize DM losses.

Michel et al. (2016) observed DM losses of 13\% in form of gas after re-ensiling without bacterial inoculant, indicating that DM loss can occur and may be associated to the initial condition of each silage and exposure to air. Effluent losses represent the amount of highly digestible soluble components leached, which, in turn, reduces silage quality. Silage compaction can remove water from plant cells, resulting in effluent production, as observed in this experiment. Michel et al. (2016) also observed an effluent production of $4 \%$ of the OM, after reensiling of untreated sorghum. It is important to highlight that the DM losses found here were significant during re-ensiling, and they should be considered in such conservation process, even when silage is exposed rapidly to air before re-ensiling (e.g., zero time).

In an extensive review on the aerobic stability of silages, Wilkinson and Davies (2013) reported that the inoculation of silages of different crop species had higher LA concentrations and residual WSC and lower values for $\mathrm{pH}$, acetic acid, and $\mathrm{NH}_{3}-\mathrm{N}$; however, a rapid increase in yeast numbers, up to five days of air exposure, there was an increase in $\mathrm{pH}$ and a decrease in WSC and LA concentrations. 
In contrast, untreated silages were quite stable aerobically and in yeast number, and showed only small changes in WSC, LA, and $\mathrm{pH}$ during 7 days of air exposure. In summary, when the addition of bacterial inoculant improved fermentation quality, it did not inhibit the growth of yeasts, and it may impair silages stability when under air exposure.

In conclusion, the exposure of sorghum silages to air up to $120 \mathrm{~h}$ was not determinant for a significant change in the fermentation profile after re-ensiling; thus, it was a safe technique for preserving the nutritional value of silage. However, other experiments should be carried out to evaluate the growth of fungi and yeasts, and the production of mycotoxins during the re-ensiling process.

\section{References}

Ashbell, G., Weinberg, Z. G., Hen, Y., \& Filya, I. (2002). The effects of temperature on the aerobic stability of wheat and corn silages. Journal of Industrial Microbiology \& Biotechnology, 28(5), 261-263. doi: $10.1038 / \mathrm{sj} / \mathrm{jim} / 7000237$

Association of Official Analytical Chemistry. (1990). Official methods of analysis (15th ed.). Arlington: AOAC.

Chen, Y., \& Weinberg, Z. G. (2014). The effect of relocation of whole-crop wheat and corn silages on their quality. Journal of Dairy Science, 97(1), 406410. doi: $10.3168 /$ jds.2013-7098

Clavin, D., Crosson, P., Grant, J., \& O’kiely, P. (2017). Red clover for silage: management impacts on herbage yield, nutritive value, ensilability and persistence, and relativity to perennial ryegrass. Grass Forage Science, 72(1), 414-431. doi: 10.1111/ gfs. 12249

Hu, W., Schmidt, R. J, McDonell, E. E., Klingerman, C. M. L., \& Kung, L., Jr. (2009). The effect of Lactobacillus buchneri 40788 or Lactobacillus plantarum MTD-1 on the fermentation and aerobic stability of corn silages ensiled at two dry matter contents. Journal of Dairy Science, 92(8), 39073914. doi: $10.3168 /$ jds.2008-1788

Johnson, R. R., Balwani, T. L., Johnson, L. J., McClure, K. E., \& Dehority, B. A. (1966). Corn plant maturity. II. Effect on in vitro cellulose digestibility and soluble carbohydrate content. Journal of Animal Science, 25(3), 617-623. doi: 10.2527/jas1966.253617x
McDonald, P., Henderson, A. R., \& Heron, S. J. E. (1991). Biochemistry of silage (2nd ed.). Bucks: Chalcombe Publication.

McGechan, M. B. (1989). A review of losses arising during conservation of grass forage: Storage losses. Journal Agricultural Engineering Research, 45, 1-30. doi: 10.1016/S0021-8634(05)80135-0

Michel, P. H. F., Gonçalves, L. C., Rodrigues, J. A. S, Keller, K. M., Raposo, V. S., Lima, E. M.,... Jayme, D. G. (2016). Re-ensiling and inoculant application with Lactobacillus plantarum and Propionibacterium acidipropionici on sorghum silages. Grass Forage Science, 72(3), 432-440. doi: 10.1111/gfs.12253

Playne, M. J., \& McDonald, P. (1966). The buffering constituents of herbage and of silage. Journal of the Science of Food and Agriculture, 17(6), 264-268. doi: 10.1002/jsfa.2740170609

Pryce, J. D. (1969). A modification of the BarkerSummerson method for the determination of lactic acid. Analyst, 94(125), 1151-1152. doi: 10.1039/ AN9699401151

Robertson, J. B., \& Van Soest, P. J. (1981). The detergent system of analysis and its application to human foods. In W. P. T. James, \& O. Theander (Eds.). The analysis of dietary fiber in food (Chap. 9, pp. 123158). New York: Marcel Dekker.

Sariçiçek, B., Yildirim, B., Kocabaş, Z., \& Özgümüş Demir, E. (2016). the effects of storage time on nutrient composition and silage quality parameters of corn silage made in plastic mini silo in laboratory conditions. Journal of Institute of Science and Technology, 6(3), 177-183. doi: 10.21597/ jist.2016321853

Tilley, J. M. A., \& Terry, R. A. (1963). A two-stage technique for the "in vitro" digestion of forage crops. Journal of the British Grassland Society, 18(2), 104111. doi: 10.1111/j.1365-2494.1963.tb00335.x

Wilkinson, J. M., \& Davies, D. R. (2013). The aerobic stability of silage: key findings and recent developments. Grass Forage Science, 68(1), 1-19. doi: 10.1111/j.1365-2494.2012.00891.X

Yahaya, M. S., Kimura, A., Harai, J., Nguyen, H. V., Kawai M., Takahashi, J., \& Matsuoka, S. (2001). Effect of length of ensiling on silo degradation and digestibility of structural carbohydrates of lucerne and orchardgrass. Animal Feed Science and Technology, 92(3), 141-148. doi: 10.1016/S03778401(01)00265-6 